\section{Still no certainty}

\section{Los Angeles}

ANY expectation that a verdict on the reality of cold fusion would soon be delivered remained unfulfilled after the special session of the Electrochemical Society's meeting in Los Angeles last Monday. Martin Fleischmann and Stanley Pons retreated on some of their claims but firmly defended their measurement of the heat output of their electrolytic cells against recent charges of sloppy experimental technique. By the end of the evening, the University of Utah researchers and their critics were still at a standoff on most of the disputatious issues, but the audience was clearly unhappy at Pons and Fleischmann's reluctance to take up offers of help from other scientists to analyse parts of the experiment more closely.

In contrast to the previous week's meeting of the American Physical Society in Baltimore (see Nature 339, 4; 4 May 1989), where Pons and Fleischmann were convicted in absentia, the Los Angeles meeting was both more sympathetic and more hopeful. Nevertheless some naysayers, notably Nathan Lewis of the California Institute for Technology, were able to get on to the programme.

Responding to assertions by Lewis in Baltimore that their temperature measurement was flawed, Pons and Fleischmann showed a video recording of one of their cells in action, in which obvious and vigorous bubbling was adduced as the means by which a uniform temperature was maintained throughout the cell. Furthermore, a dye (phenolphthalein) introduced into the electrolyte was visibly well-mixed in about 20 seconds. But Lewis said later on that the calibration of the cell's energy output was still of unquantified accuracy. In Pons and Fleischmann's set-up, a relation between heat flow and temperature differential is obtained by the use of a resistive heater, through which a measured energy is passed before electrolysis is begun; what remains undemonstrated, according to Lewis, is that the calibration, performed when the electrolyte is still, is a useful measure of what happens when the cell is working and the electrolyte is seething with evolved gases.

But on the question of whether fusion by-products had been seen there was a retreat. Fleischmann said that criticisms of their gamma-ray line at $2.2 \mathrm{MeV}$, that it was too narrow and too weak to be the neutron-capture line they claimed, were ones that he too had worried about and expressed to Pons before publication, and that they were working on new measurements. And claims that a significant production of helium- 4 had been detected (see Nature 338, 691; 27 April 1989) were premature.

Support for cold fusion came from
Robert Huggins of Stanford University, who repeated his claim that a heavy-water electrolytic cell ran consistently hotter than an identical light-water one, and from a number of speakers from Texas A\&M University, who showed calorimetric data indicating that a palladium cathode in a heavy-water electrolyte produced excess heat, while platinum in heavy water and palladium in light water produced nothing out of the ordinary. Fleischmann declared that any suggestions that control experiments done with ordinary water were yielding excess heat comparable to that produced with heavy water were "total nonsense",

But Steven Jones of Brigham Young University emphasized the need to have detections of some fusion products; anomalous heat alone does not prove that nuclear processes are at work. It was mentioned repeatedly that helium is retained by palladium for up to 12 years, and that if heat was being generated at the rate claimed by Pons and Fleischmann, a postmortem of an electrode would reveal high helium concentrations. Members of the audience offered to analyse a piece of one of the Utah electrodes, but Pons declined, saying that arrangements had already been made, with a laboratory he would not identify, to do similar analyses.
At the end of the session, no useful resolution had been reached. Those who argued that cold fusion works also admitted that reproducibility was difficult. Robert Huggins claimed that the palladium had to be cast, not annealed, and that it had to be purged of hydrogen; U. Landau of Case Western Reserve University described some preliminary suggestions of excess heat from annealed electrodes. J. Bockris of Texas A\&M University said that out of twenty palladium electrodes tested by three different collaborations at the University, only 5 or 6 produced heat. To explain these mystifying variations, Bockris argued that fusion occurs when large concentrations of deuterium build up around defects and dislocations in the palladium (see this week's issue, Nature 339, 105; 1989), but this made no impression on Nathan Lewis who said that the group at the California Institute of Technology had tried 50 electrodes, some cast, some annealed, and none of them worked.

No true discussion between boosters and critics occurred. At a later press conference, Fleischmann said it was difficult for him to respond to Lewis's criticisms because he had not seen all the data in a published paper, with all details made available. According to Pons, they hoped to publish a full paper describing the calorimetry behind his and Fleischmann's results later in the summer. David Lindley

\title{
Row in the Senate over altered testimony
}

\section{Washington}

AN ATTEMPT by US President George Bush's Office of Management and Budget (OMB) to modify congressional testimony on global warming caused outrage earlier this week at a Senate subcommittee hearing on "Possible climate surprises predicting greenhouse warming". James Hansen, head of the US National Aeronautics and Space Administration (NASA)'s Goddard Institute for Space Studies said that OMB altered his written testimony and made him appear to negate his own predictions of global climate changes by saying they were only "estimates" and not "reliable predictions".

The hearing came as administration officials attending the United Nations Intergovernmental Panel on Climate Change in Geneva were briefed to go slow and recommend more studies during discussions of international agreements to protect the atmosphere. The Bush administration reacted coldly to a Senate resolution calling on the United States to take the lead in setting up an international convention to slow global warming.

Senator Albert Gore, Jr (Democrat, Tennessee), who chaired the hearing, said the changes in Hansen's testimony had been made by "a nameless, faceless bureaucrat" from a "kind of science Politburo". Preventing the best scientists from giving their best data to Congress "is a form of science fraud" and an "outrage of the first order of magnitude", said Gore. Committee member Senator Richard Bryan (Democrat, Nevada) added that Bush seemed to be fulfilling his campaign promise to "counter the greenhouse effect with the White House effect" by using the "whitewash effect" instead.

Hansen said that more than a year ago he chose to appear before Congress as a private citizen rather than accept changes to his testimony made by OMB. All formal testimony by government employees including government scientists - must first be vetted by the administration.

At a press briefing, White House spokesman Marlin Fitzwater defended the Administration's action by saying “OMB's position was that it was a policy issue and not a scientific one". He conceded that the changes were made by an OMB employee at least "four levels down from the top", and that Hansen was in his rights to present his own conclusions during oral questioning, even if they differed from his approved testimony. When asked if he was worried about retributions for his candour, Hansen replied "I am now". 